\title{
ZONASI TINGKAT KERAWANAN BANJIR DENGAN SISTEM INFORMASI GEOGRAFIS PADA DAS CIDURIAN KAB.SERANG, BANTEN
}

\author{
Probo Kusumo ${ }^{1}$, Evi Nursari ${ }^{2}$ \\ ${ }^{1}$ Program Studi Teknik Informatika, Universitas Indraprasta PGRI \\ Email: bow.itsm@gmail.com \\ ${ }^{2}$ Pengelolaan Daerah Aliran Sungai, Institut Pertanian Bogor \\ Email: ev.nursari@gmail.com
}

\begin{abstract}
Abstrak
Fenomena banjir sering melanda suatu kawasan daerah aliran sungai yang tidak mampu menampung air hujan yang turun karena besarnya air hujan melebihi kapasitas tampung dari DAS itu sendiri. Daerah Aliran Sungai Cidurian dimana sungai utamanya Sungai Cidurian hampir setiap tahun mengalami banjir di beberapa wilayah di DAS Cidurian hilir. Hal tersebut menyebabkan terganggunya aktivitas masyarakat di sekitar DAS.Tujuan dari penelitian ini adalah melakukan zonasi tingkat kerawanan banjir di DAS Cidurian berdasarkan sistem informasi geografis sehingga dapat ditentukan daerah mana yang memerlukan prioritas pengelolaan Daerah Aliran Sungai. Metode yang digunakan dalam penelitian ini untuk memetakan tingkat kerawanan banjir dengan teknik skoring dan pembobotan. Hasil menunjukan wilayah yang tergolong sangat rawan banjir sebagian besar di daerah hilir DAS yang berada pada dataran rendah dengan penggunaan lahan sebagian besar adalah lahan terbuka dan terbangun yaitu di Kabupaten Serang dan Tangeran, sementara wilayah yang tergolong tidak rawan banjir adalah wilayah-wilayah dataran tinggi dengan penggunaan lahan yang masih banyak vegetasinya yaitu wilayah hulu DAS yang berada di Kabupaten Bogor.
\end{abstract}

Kata Kunci: Daerah aliran sungai, banjir, Sistem informasi geografis, zonasi, kerawanan

\section{Pendahuluan}

Banjir merupakan peristiwa terjadinya genangan pada daerah datar sekitar sungai sebagai akibat meluapnya air sungai yang tidak mampu ditampung oleh sungai. Selain itu, banjir adalah interaksi antara manusia dengan alam dan sistem alam itu sendiri. Bencana banjir ini merupakan aspek interaksi manusia dengan alam yang timbul dari proses dimana manusia mencoba menggunakan alam yang bermanfaat dan menghindari alam yang merugikan manusia (Solahuddin, 2014). Fenomena banjir sering melanda suatu kawasan daerah aliran sungai yang tidak mampu menampung air hujan yang turun karena besarnya air hujan melebihi kapasitas tampung dari DAS itu sendiri.

Salah satu daerah aliran sungai Cidurian dimana sungai utamanya Sungai Cidurian hampir setiap tahun mengalami banjir di beberapa wilayah di DAS Cidurian hilir. Banjir yang terjadi di DAS Cidurian salah satunya disebabkan oleh tingginya curah hujan sehingga tanggul penahan dan drainase yang ada di DAS tersebut tidak mampu menahan tingginya aliran sungai. Fluktuasi debit yang tidak normal digambarkan oleh debit aliran sungai yang sangat tinggi sehingga sungainya meluap dan menyebabkan banjir pada saat musim hujan, kemudian debit aliran sungai menjadi sangat rendah pada saat musim kemarau. Hal itu menyebabkan terganggunya aktivitas kehidupan masyarakat di sekitar Sungai Cidurian (Dinas Sumber Daya Air dan Pemukiman Provinsi Banten 2013). Disamping itu, terdapat berbagai faktor biofisik yang mempengaruhi terjadinya banjir di DAS Cidurian.

DAS Cidurian merupakan salah satu DAS yang sungainya mengalir dari sumber mata air yang berada di Komplek Gunung Gede ke Laut Jawa melalui Kabupaten Bogor, Kabupaten Lebak, Kabupaten Serang dan Kabupaten Tangerang. Sungai Cidurian merupakan salah satu penyangga kehidupan bagi masyarakat Provinsi Banten yaitu sebagi sumber pasokan air bagi kebutuhan rumah tangga, pertanian, perikanan maupun industri. Terdapat berbagai aktivitas 
di DAS Cidurian seperti pertanian, perikanan, industri, penambangan pasir serta aktifitas di sekitar pemukiman masyarakat.

Peta kerawanan banjir merupakan bagian dari sistem peringatan dini (early warning system) dari bahaya dan resiko banjir sehingga akibat dari bencana banjir dapat diperkirakan dan pada akhimya dapat diminimalisir.Peta tingkat kerawanan banjir yang baik adalah peta yang memiliki tingkat akurasi yang tinggi. Peta tersebut diperoleh dengan menggunakan Teknik SIG (Sistem Informasi Geografis) berdasarkan metode penilaian, pembobotan dan proses tumpang susun (overlay) berdasarkan faktor meteorologi dan karakteristik Daerah Aliran Sungai (DAS) yang berpengaruh terhadap terjadinya banjir. Teknik SIG ini mempunyai kelebihan dalam hal kecepatan pemrosesan, kemudahan dalam penyajian, lebih efektif dan efisien serta akurat bila dibandingkan dengan pengerjaan secara manual (Suhardiman, 2012).

Penelitian ini bertujuan untuk melakukan zonasi tingkat kerawanan banjir di DAS Cidurian berdasarkan sistem informasi geografi sehingga dapat ditentukan daerah mana yang memerlukan prioritas pengelolaan Daerah Aliran Sungai sehingga dapat dijadikan masukan bagi pengelola DAS Cidurian.

\section{Tinjauan Pustaka}

Pada PP No. 37 tahun 2012, daerah aliran sungai didefinisikan sebagai suatu wilayah daratan yang membentuk satu kesatuan dengan sungai dan anaka-anak sungainya.Daerah ini mempunyai fungsi sebagai penampung, penyimpan dan sebagai daerah alir air ke suatu badan air secara alami.Batas DAS di darat merupakan pemisah topografis, seperti punggung bukit, sedangkan batas pada laut adalah daerah perairan yang masih dipengaruhi oleh aktifitas daratan.

Pengelolaan DAS dan pemanfaatan yang salah oleh manusia dapat menyebabkan terjadinya kerusakan pada DAS. Diantara penyebabnya adalah semakin meningkatnya perubahan penggunaan lahan terutama di daerah resapan menjadi lahan pertanian ataupun pemukiman, akibat peningkatan jumlah penduduk yang menyebabkan meningkatnya kebutuhan akan lahan. DAS yang telah rusak tidak mampu menahan dan menyimpan air yang jatuh diatasnya, akibatnya air yang jatuh tidak dapat masuk ke dalam tanah, melainkan menjadi aliran permukaan. Berkurangnya kapasitas infiltrasi air ke dalam tanah akan mengurangi pengisian kembali air bawah tanah (ground water) yang menyebabkan terjadinya kekeringan pada saat musim kemarau dan banjir pada saat musim hujan (Firmansyah, 2009).

Perkembangan penggunaan lahan di sejumlah daerah aliran sungai-sungai di Indonesia dalam tiga dasawarsa terakhir ini telah memberi dampak berupa peningkatan frekuensi, debit, dan volume banjir yang telah menggenangi wilayah permukiman dan infrastruktur umum yang mengakibatkan kerusakan dan kerugian material dan non-material (Pawitan, 2003).

Banjir merupakan permasalahan yang umum yang terjadi di sebagian wilayah Indonesia, terutama di daerah yang padat penduduknya seperti di daerah perkotaan.Penyebab banjir sendiri bisa terjadi karena berbagai hal baik alam maupun manusia.Banjir dapat diakibatkan oleh peristiwa alam seperti curah hujan dalam jangka waktu yang lama, terjadinya banjir tanah hingga hanya menyisakan batuan, dan tidak ada resapan air (Santosa, 2015).

Daerah rawan banjir merupakan daerah yang berpotensi mengalami banjir. Daerah rawan banjir ditentukan berdasarkan parameter alami DAS, meliputi bentuk lahan, meandering/pembelokan sungai, pertemuan percabangan sungai, drainase lahan/kelerengan rata-rata DAS dan parameter manajemen yaitu keberadaan bangunan air pengendali banjir. Masing-masing parameter diberi skor dan bobot sesuai pengaruhnya dalam penentuan daerah rawan banjir (Paimin, 2006). 
Ada beberapa faktor yang mempengaruhi terjadinya banjir di suatu daerah yaitu curah hujan, kemiringan lereng, jenis tanah dan penggunaan lahan.Tebal hujan yang tinggi yang turun pada DAS lebih memungkinkan menjadi penyebab timbulnya banjir daripada curah hujan yang turun pada DAS dengan tebal yang rendah. Hal ini disebabkan curah hujan dengan tebal yang tinggi akan lebih besar memberikan sumbangan debit air ke DAS dan apabila daya tampung dari sungai terlampaui maka akan mengakibatkan banjir (Loebis, 1992). Daerah yang mempunyai tebal hujan yang tinggi maka daerah tersebut akan lebih berpengaruh terhadap kejadian banjir. Berdasarkan hal tersebut maka untuk pemberian skor ditentukan aturan sebagai berikut yaitu : semakin tinggi tebal curah hujan maka skor untuk tingkat kerawanan semakin tinggi.

Kemiringan lahan semakin tinggi maka air yang diteruskan semakin tinggi. Air yang berada pada lahan tersebut akan diteruskan ke tempat yang lebih rendah semakin cepat jika dibandingkan dengan lahan yang kemiringannya rendah (landai). Dengan demikian, maka semakin besar derajat kemiringan lahan maka skor untuk kerawanan banjir semakin kecil (Suhardiman, 2012).

Jenis tanah sangat berpengaruh terhadap proses infiltrasi. Tanah yang memiliki tekstur halus memiliki tingkat infiltrasi yang rendah sehingga menimbulkan aliran permukaan (run off) meningkat (Heryani, 2013).

Vegetasi pada lahan akan berfungsi: 1) Untuk mengurangi energi kinetik hujan; 2) Mengurangi kecepatan run off; 3) Transpirasi sehingga infiltrasi berjalan cepat; dan 4) Memperbaiki stabilitas agregat. Vegetasi yang nampak di permukaan tanah mencerminkan besarnya penutupan lahan oleh tajuk tanaman. Semakin banyak lahan yang tertutup, kerusakan tanah akan semakin kecil dan sebaliknya lahan yang semakin terbuka akan menyebabkan tanah memiliki potensi banjir yang besar (Rajiman, 2013).

\section{Metodologi Penelitian}

\section{Lokasi Penelitian}

Secara geografis letak DAS Cidurian terletak antara $106^{\circ} 00^{\prime}$ dan $106^{\circ} 30^{\prime}$ Bujur Timur serta $5^{0} 00^{\prime}$ dan $6^{0} 40^{\prime}$ Lintang Selatan. Luas DAS Cidurian kurang lebih $854 \mathrm{~km}^{2}$ dengan panjang sungai $95.47 \mathrm{~km}$.

\section{Bahan dan alat}

Bahan yang digunakan dalam penelitian teridri dari layer curah hujan, lereng, penggunaan lahan, jenis tanah, jaringan sungai, administrasi dan batas DAS Cidurian. Sementara, Alat yang digunakan dalam melaksanakan penelitian ini antara lain: Perangkat lunak Ms. Excel, Arc GIS 10.1, form Expertis Judgement dan komputer.

\section{Pengumpulan data}

Data-data yang diperlukan merupakan data sekunder yang didapatkan dari lembaga atau instansi terkait seperti Balai Besar Wilayah Sungai Cidanau, Ciujung, Cidurian dan BMKG kota Serang.

\section{Pengolahan dan Analisis Data \\ a. Operasi Spasial}

Layer-layer yang didapatkan belum bisa digunakan secara langsung, oleh sebab itu perlu dilakukan operasi spasial agar bisa dianalisis ke tahap selanjutnya. Untuk curah hujan, datanya berupa data curah hujan di setiap stasiun, oleh sebab itu perlu dilakukan analisis keruangan berupa interpolasi data curah hujan dari setiap stasiun sehingga dapat diketahui data rata-rata curah hujan tahunannya untuk setiap wilayah. Kemudian dilakukan proses clip untuk layer penggunaan lahan dengan batas DAS nya karena data yang didapat berupa layer penggunaan lahan untuk pulau jawa,danuntuk jaringan sungai dilakukan proses buffer menggunakan tools Multiple Ring Buffer pada Analysis Tools. Pengaturan jarak pada Distances; 25 m, 50 m, 75 m, 100 m, 125m „, 1000m. dilakukan pembuatan layer slope, elevasi, dan jaringan sungai dari layer kontur. 


\section{b. Analisis Atribut}

Analisis atribut dalam hal ini adalah pemberian nilai skor dan pembobotan.Pengskoran dimaksudkan sebagai pemberian skor terhadap masing-masing kelas. Pemberian skor ini didasarkan pada pengaruh kelas tersebut terhadap besarnya banjir. Adapun pemberian skor dilandasi beberapa filosofi, yaitu : 1. Wilayah dengan curah hujan tinggi memiliki kerentanan banjir lebih tinggi; 2. Kemiringan lereng yang landai memiliki kerentanan banjir lebih tinggi dari lereng yang curam; 3 . Tanah dengan tekstur sangat halus memiliki peluang kejadian banjir yang tinggi, sedangkan tekstur yang kasar memiliki peluang kejadian banjir yang rendah; 4. Bentuk lahan yang lebih landai hingga cekung memiliki kerentanan lebih tinggi; 5. Semakin dekat dengan sungai atau badan air, maka kemungkinan terjadinya genangan atau banjir yang berasal dari luapan sungai lebih besar; 6. Penggunaan lahan yang dianggap rentan terhadap banjir adalah penggunaan lahan yang lebih berpengaruh pada air limpasan yang melebihi laju infiltrasi. Pembobotan didapatkan berdasarkan pendapat dari para ahli dengan menggunakan form expertise judgement.

\section{c. Overlay dan Proyeksi Peta}

Setelah selesai analisis atribut, kemudian layer - layer yang sudah diberikan nilai skor dan pembobotan beserta layer administrasi dilakukan overlay (intersect), setelah itu proyeksi peta di rubah menjadi UTM wgs 1984 Zona 48 S (wilayah Serang, Banten) menggunakan Tools Projection and Transformation pada Data Management Tools.

Layer hasil overlay yang sudah dirubah proyeksinya kemudian dilakukan proses perhitungan luas untuk menghitung luasan daerah berdasarkan tingkat kerawanan banjir dengan menggunakan fungsi calculate geometri.

\section{Analisis Kerawanan Banjir}

Nilai kerawanan suatu daerah terhadap banjir ditentukan dari total penjumlahan skor enam parameter yang berpengaruh terhadap banjir (Curah Hujan, Kelerengan, Ketinggian Lahan, Jenis Tanah, Penggunaan Lahan dan Buffer Sungai). Menurut Kingma (1991) nilai kerawanan ditentukan, dengan menggunakan persamaan sebagai berikut:

Keterangan :

$$
K=\Sigma W i x X i
$$

$\mathrm{K}=$ Nilai kerawanan

$\mathrm{W} i=$ Bobot untuk parameter ke-i

$\mathrm{X} i=$ Skor kelas parameter ke-i

\section{Hasil dan Pembahasan}

\section{Parameter-Parameter Tingkat Kerawanan Banjir}

\section{a. Curah hujan}

Daerah yang curah hujannya tinggi akan lebih berpengaruh terhadap kejadian banjir, dimana semakin tinggi curah hujan di suatu daerah maka akan semakin tinggi pula untuk potensi banjir. Berdasarkan hal tersebut, maka pemberian skor untuk daerah curah hujan tersebut akan semakin tinggi. Berdasarkan data curah hujan di wilayah DAS Cidurian, data curah hujan dibagi ke dalam lima kelas, dimana curah hujan diatas $2500 \mathrm{~mm}$ memiliki skor tertinggi yaitu 9 sementara curah hujan dibawah $1000 \mathrm{~mm}$ memiliki skor terendah yaitu 1 (Tabel 1).

Tabel 1.Skor Parameter Curah Hujan

\begin{tabular}{lcc}
\hline No & Kelas & Skor \\
\hline 1 & $>2500$ & 9 \\
2 & $2001-2500$ & 7 \\
3 & $1501-2000$ & 5 \\
4 & $1000-1500$ & 3 \\
5 & $<1000$ & 1 \\
\hline
\end{tabular}




\section{b. Kemiringan Lereng}

Kemiringan lereng yang datar memiliki tingkat kerawanan banjir yang lebih tinggi dibandingkan kemiringan lereng yang curam, maka dalam pemberian skor, kemiringan lereng yang datar (0-8\%) memiliki skor tertinggi yaitu 9, sementara kemiringan lereng yang curam $(>45 \%)$ memiliki skor terendah yaitu 1.Berdasarkan data kemiringan lerengdi DAS Cidurian, kemiringan lereng datar tersebar di daerah hilir sementara lereng curam tersebar di daerah hulu (Tabel 2).

Tabel 2 Skor Parameter Kemiringan Lereng

\begin{tabular}{llc}
\hline No & Kelas & Skor \\
\hline 1 & $0-8 \%$ & 9 \\
2 & $8-15 \%$ & 7 \\
3 & $15-25 \%$ & 5 \\
4 & $25-40 \%$ & 3 \\
5 & $>40 \%$ & 1 \\
\hline
\end{tabular}

\section{c. Jenis Tanah}

Penetapan skor jenis tanah didasarkan pada tekstur dari masing-masing jenis tanah.Tanah dengan tekstur sangat halus memiliki peluang kejadian banjir yang tinggi, sedangkan tekstur yang kasar memiliki peluang kejadian banjir yang rendah.Hal ini disebabkan semakin halus tekstur tanah menyebabkan air aliran permukaan yang berasal dari hujan maupun luapan sungai sulit untuk meresap ke dalam tanah, sehingga terjadi penggenangan.Berdasarkan hal tersebut, pemberian skor tertinggi (9) diberikan pada jenis tanah yang memiliki tekstur sangat halus seperti vertisol, oksisol, sementara skor terendah diberikan pada tanah-tanah yang memiliki tekstur kasar seperti spodosol, andisol (Tabel 3).

Tabel 3. Skor Parameter Jenis Tanah

\begin{tabular}{lll}
\hline No & Kelas & Skor \\
\hline 1 & Vertisol, oxisol & 9 \\
2 & Alfisol, Ultisol, Molisol & 7 \\
3 & Inceptisol & 5 \\
4 & Entisol, Histosol & 3 \\
5 & Spodosol, Andisol & 1 \\
\hline
\end{tabular}

\section{d. Penggunaan lahan}

Penggunaan lahan akan berperan pada besarnya air limpasan hasil dari hujan yang telah melebihi laju infiltrasi. Daerah yang banyak ditumbuhi oleh pepohonan akan sulit sekali mengalirkan air limpasan, hal ini disebabkan besarnya kapasitas serapan air oleh pepohonan dan lambatnya air limpasan mengalir disebabkan tertahan oleh akar dan batang pohon. Lahan yang banyak ditanami oleh vegetasi maka air hujan akan banyak diinfiltrasi dan lebih banyak waktu yang ditempuh oleh limpasan untuk sampai ke sungai sehingga kemungkinan banjir lebih kecil daripada daerah yang tidak ditanami oleh vegetasi (Seyhan, 1995). Oleh sebab itu, pemberian skor tertinggi (9) ditujukan untuk penggunaan lahan terbuka, badan air dan tambak, karena pada penggunaan lahan tersebut sebagian besar air hujan yang jatuh akan langsung menjadi aliran permukaan dan mengalir ke sungai sehingga dapat berpotensi menjadi banjir. Sementara lahan-lahan bervegetasi, potensi untuk terjadinya banjir akan semakin kecil sehingga pemberian skor rendah (1) (Tabel 4). 
Tabel 4. Skor Parameter Penggunaan Lahan

\begin{tabular}{llc}
\hline No & Kelas & Skor \\
\hline 1 & Lahan terbuka-badan air-tambak & 9 \\
2 & Pemukiman- Sawah & 7 \\
3 & Perkebunan-Tegalan & 5 \\
4 & Kebun campuran-Semak belukar & 3 \\
5 & Hutan & 1 \\
\hline
\end{tabular}

\section{e. Jarak wilayah terhadap Sungai}

Semakin dekat jarak suatu wilayah dengan sungai, maka peluang terjadinya banjir akan semakin tinggi. Oleh sebab itu, pemberian skor akan semakin tinggi apabila jarak suatu wilayah dengan sungai semakin dekat yaitu jarak < 25 m ( skor 9). Sebaliknya, apabila jarak suatu wilayah semakin jauh dengan sungai maka skornya semakin rendah, diberikan skor 1 (Tabel 5).

\section{Tabel 5. Skor Parameter Buffer Jaringan Sungai}

\begin{tabular}{llc}
\hline No & Kelas & Skor \\
\hline 1 & $0-25 \mathrm{~m}$ & 9 \\
2 & $25-50 \mathrm{~m}$ & 7 \\
3 & $50-75 \mathrm{~m}$ & 5 \\
4 & $75-100 \mathrm{~m}$ & 3 \\
5 & $>100 \mathrm{~m}$ & 1 \\
\hline
\end{tabular}

\section{f. Elevasi}

Elelvasi (ketinggian) berpengaruh terhadap terjadinya banjir, karena berdasarkan sifat air, air mengalir dari daerah tinggi ke daerah rendah. Dimana daerah yang mempunyai ketinggian yang lebih tinggi potensinya kecil untuk terjadi banjir,sedangkandaerah dengan ketinggian rendah lebih berpotensi untuk terjadinya banjir.Pemberian skor pada kelas ketinggian yang lebih tinggi lebih kecil daripada skor untuk kelas ketinggian yang rendah (Tabel 6).

\begin{tabular}{llc}
\multicolumn{3}{c}{ Tabel 6. } \\
\hline No & Elevasi & Parameter Elevasi \\
\hline 1 & $0-20 \mathrm{~m}$ & Skor \\
2 & $21-50 \mathrm{~m}$ & 9 \\
3 & $51-100 \mathrm{~m}$ & 7 \\
4 & $101-300 \mathrm{~m}$ & 5 \\
5 & $>300 \mathrm{~m}$ & 3 \\
\hline
\end{tabular}

\section{Pembobotan}

Pembobotan menggunakan metode expertise judgement yaitu pendapat para ahli. Nilai pembobotan dilakukan secara kualitatif tergantung pada pendapat "para ahli" tersebut. Berdasarkan pendapat ahli yang ditunjuk, bobot tertinggi diberikan kepada parameter penggunaan lahan, karena menurut pendapat ahli tersebut rawan atau tidaknya banjir disuatu daerah sangat ditentukan oleh penggunaan lahan di daerah tersebut, dimana semakin terbuka lahan tersebut maka potensi banjir akan semakin tinggi. Disusul dengan parameter elevasi dan buffer sungai, keduanya memiliki bobot yang sama karena keduanya memiliki pengaruh 
yang sama besar, dimana semakin rendah ketinggian wilayah suatu daerah serta semakin dekat jarak wilayah tersebut dengan sungai, maka potensi banjir akan semakin besar. Selanjutnya curah hujan, bobot curah hujan tidak terlalu tinggi namun cukup berpengaruh dalam masalah banjir, dimana semakin tinggi curah hujannya kemungkinan banjir akan semakin tinggi, namun pengaruh besarnya curah hujan terhadap banjir tidak akan berlaku pada daerah-daerah dataran tinggi karena kemungkinannya kecil untuk menimbulkan banjir sehingga bobotnya tidak terlalu tinggi. Kemudian, jenis tanah dan kemiringan lereng, menurut pendapat ahli bahwa pengaruh jenis tanah dan kemiringan lereng pengaruhnya tidak terlalu besar terhadap banjir dibandingkan parameter lainnya sehingga bobot yang diberikan paling rendah dibandingkan bobot lainnya.

\begin{tabular}{cc} 
Tabel 7. Pembobotan Parameter Kerawanan B \\
\cline { 2 - 2 } Parameter & Bobot (\%) \\
\hline Curah hujan & 15 \\
Kelerengan & 10 \\
Jenis Tanah & 10 \\
Penggunaan Lahan & 25 \\
Elevasi & 20 \\
Buffer Sungai & 20 \\
\hline Total & $\mathbf{1 0 0}$ \\
\hline
\end{tabular}

\section{Analisis Tingkat Kerawanan Banjir}

Tingkat kerawanan banjir merupakan peristiwa terbenamnya daratan (yang biasanya kering) karena volume air yang meningkat pada setiap unit lahan yang diperoleh berdasarkan nilai kerawanan banjir.Sebagian besar daerah yang tanahnya mempunyai daya serapan air yang buruk (tekstur tanah), atau jumlah curah hujan melebihi kemampuan tanah untuk menyerap air. Ketika hujan lebat turun, yang kadang terjadi adalah banjir secara tiba-tiba yang diakibatkan terisinya saluran air kering dengan air (Suhardiman, 2012).

Formula yang digunakan dalam proses overlay dengan menggunakan metode aritmatika adalah sebagai berikut:

$$
K B=2 \times \mathrm{CH}+1 \times \mathrm{KL}+1 \times J \mathrm{~T}+2.5 \times \mathrm{PL}+1.5 \times E+2 \times B S
$$

Keterangan : KB : Kerawanan Banjir, JT : Jenis Tanah, KL : Kemiringan Lereng,

CH : Curah Hujan, E : Elevasi, PL : Penggunaan Lahan, BS : Buffer Sungai

Berdasarkan hasil analisis tingkat kerawanan banjir di DAS Cidurian, didapatkan klasifikasi tingkat kerawanan banjir (Tabel 8):

Tabel 8. Tingkat Kerawanan Banjir DAS Cidurian

\begin{tabular}{cccc}
\hline No & Tingkat Kerawanan & Luas (Ha) & \% \\
\hline 1 & Tidak Rawan & $33,679.85$ & 40.18 \\
2 & Rawan & $42,547.28$ & 50.76 \\
3 & Sangat Rawan & $7,589.85$ & 9.05 \\
\hline & Total & $\mathbf{8 3 , 8 1 6 . 2 7 4}$ & $\mathbf{1 0 0}$ \\
\hline
\end{tabular}

a. Zona Tidak Rawan Banjir

Zona tidak rawan banjir dapat dikatakan sebagai daerah yang paling aman terhadap kemungkinan terlanda banjir. Hal ini disebabkan karena pada daerah ini tergolong dataran tinggi, dengan penggunaan lahan yang masih banyak vegetasi, serta jaraknya jauh dari sungai. Kemiringan lereng yang curam menyebabkan aliran limpasan permukaan menjadi 
cepat dan tidak akan menggenangi daerah ini, sehingga resiko banjir menjadi kecil. Berdasarkan hasil analisis tingkat kerawanan banjir yang tergolong tidak rawan terdiri dari 33,679.85 ha.Daerah-daerah yang termasuk wilayah ini adalah daerah yang berada di kabupaten Bogor (17,385.05 ha) dan Kab. Lebak ( 14,834.61) (Tabel 9) yang termasuk wilayah hulu DAS Cidurian.

b. Zona Rawan Banjir

Zona ini adalah wilayah yang termasuk potensial kritis terhadap banjir .wilayah ini berada pada daerah dataran rendah dan sebagian terletak di wilayah tengah DAS. Jenis banjir pada daerah ini tidak terlalu tinggi umumnya bersifat genangan sementara akibat curah hujan yang tinggi dan drainase yang buruk. Selain itu, jenis tanah di daerah ini adalah lempung sehingga tanah akan cepat jenuh jika curah hujan tinggi akibatnya proses infiltrasi akan berjalan lambat hingga akhirnya menimbulkan genangan air di permukaan. Genangan tersebut akan mengalir ke tempat yang lebih rendah yaitu di sekitar bantaran sungai. Luas wilayah yang tergolong ke dalam zona rawan sebesar 42,547.28 ha, dimana zona ini sebagian besar berpotensi di wilayah Kabupaten Serang dengan luasan 14,216.52 ha (Tabel 9).

\section{c. Zona Sangat Rawan Banjir}

Zona tinggi adalah wilayah yang termasuk kategori kritis terhadap kerawanan banjir.Wilayah yang tergolong kedalam sangat rawan terhadap banjir sebagian besar berada di hilir DAS yaitu Kab.Tangerang (4,819.87 ha) dan Serang (2,153.89 ha) (Tabel 9), karena wilayah tersebut memiliki elevasi yang rendah, penggunaan lahan yang cenderung sedikit vegetasi, karena sebagian besar wilayahnya adalah wilayah terbangun dan terbuka tanpa vegetasi sehingga menyebabkan tingginya aliran permukaan yang langsung mengalir ke sungai.Luas wilayah yang tergolong zona sangat rawan sebesar 7,589.85 ha (Tabel 8).

Berdasarkan dari ke tiga zona kerawanan banjir, proporsi zonasi tertinggi adalah zona rawan banjir yaitu sebesar $50.76 \%$ dari total luas wilayah DAS Cidurian, disusul zona tidak rawan sebesar $40.18 \%$, sedangkan zona sangat rawan hanya $9.05 \%$. Adapun peta tingkat kerawanan banjir disajikan pada Gambar 3.

Tabel 9. Tingkat Kerawanan Banjir DAS Cidurian Berdasarkan Wilayah

\begin{tabular}{rlrrrr}
\hline \multirow{2}{*}{ No } & \multirow{2}{*}{ Kabupaten } & \multicolumn{3}{c}{ Tingkat Kerawanan (Ha) } & \multirow{2}{*}{ Total (Ha) } \\
\cline { 3 - 5 } & & \multicolumn{1}{c}{ Rawan } & Sangat Rawan & Tidak Rawan & \\
\hline 1 & Kab.Bogor & $3,030.84$ & 489.00 & $17,385.05$ & $30,904.89$ \\
2 & Kab.Lebak & $4,678.75$ & 126.40 & $14,834.61$ & $19,639.76$ \\
3 & Kab.Serang & $16,216.52$ & $2,153.89$ & 276.57 & $18,646.99$ \\
4 & Kab.Tangerang & $8,621.16$ & $4,819.87$ & $1,183.61$ & $14,624.64$ \\
\hline & Total & $\mathbf{4 2 , 5 4 7 . 2 8}$ & $\mathbf{7 , 5 8 9 . 1 5}$ & $\mathbf{3 3 , 6 7 9 . 8 5}$ & $\mathbf{8 3 , 8 1 6 . 2 7}$ \\
\hline
\end{tabular}




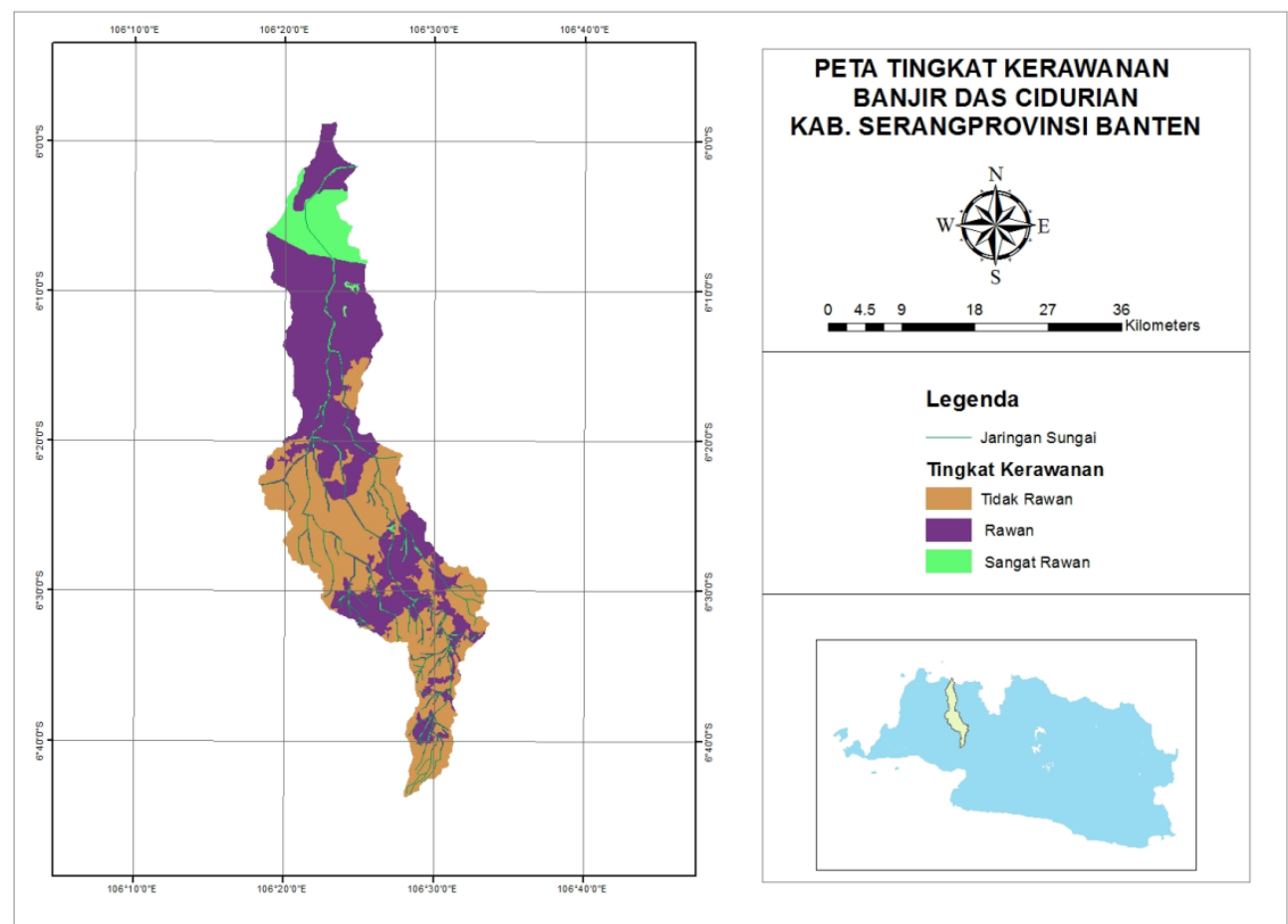

Gambar 3. Peta Tingkat Kerawanan Banjir DAS Cidurian

\section{Simpulan dan Saran}

Dalam penentuan tingkat kerawanan banjir dipengaruhi oleh parameter penggunaan lahan, kemiringan lereng, elevasi, jenis tanah, curah hujan dan kedekatan dengan sungai. Berdasarkan pembobotan dengan metode Expert Judgment, 3 variabel yang menjadi penentu tingkat kerawanan banjir adalah penggunaan, elevasi, dan kedekatandengan sungai.Bobot nilai variabel tersebut masing-masing adalah $25 \%, 20 \%$ dan $20 \%$. Wilayah yang tergolong sangat rawan banjir sebagian besar di daerah hilir DAS yang berada pada dataran rendah dengan penggunaan lahan sebagian besar adalah lahan terbuka dan terbangun yaitu di Kabupaten Serang dan Tangeran, sementara wilayah yang tergolong tidak rawan banjir adalah wilayah-wilayah dataran tinggi dengan penggunaan lahan yang masih banyak vegetasinya yaitu wilayah hulu DAS yang berada di Kabupaten Bogor. Formula untuk tingkat kerawanan banjir adalah $K B=2 \times \mathrm{CH}+1 \times \mathrm{KL}+1 \times J \mathrm{~T}+2.5 \times \mathrm{PL}+1.5 \times E+2 \times B S$. Perlu adanya penelitian lanjutan untuk menentukan skenario pengelolaan apa saja yang perlu dilakukan untuk mengatasi kerawanan banjir berdasarkan peta kerawanan banjir yang telah ada.

\section{Daftar Pustaka}

Arifin, Y.I., \&Kasim, M. (2009). Penentuan zonasi daerah tingkat kerawanan banjir di Kota Gorontalo Provinsi Gorontalo untuk mitigasi bencana.Yogyakarta: UGM.

Dinas Sumber Daya Air dan Pemukiman (DSDAP) Provinsi Banten. (2015). Profil sungai kewenangan Provinsi Banten. Retrieved from:http://www.dsdap.bantenprov.go.id/.

Heryani, R.,Paharuddin, Arif, S. (2013). Analisis Kerawanan Banjir Berbasis Spasial Menggunakan Analytical Hierarchy Process (AHP) Kabupaten Maros. Makassar: Universitas Hasanuddin. 
Loebis, J.(1992). “Banjir Rencana Untuk Bangunan Air”. Jakarta :Departemen Pekerjaan Umum.

Paimin,Sukresno,\&Purwanto.(2006). Sidik Cepat Degradasi Sub Daerah Aliran Sungai (Sub $D A S)$. Bogor: Balai Penelitian dan Pengembangan Kehutanan.

Pawitan, H. (2003). Perubahan Penggunaan Lahan Dan Pengaruhnya Terhadap Hidrologi Daerah Aliran Sungai.Bogor: Institut Pertanian Bogor.

Santosa, W.W., Suprayogi, A., \& Sudarsono, B. (2015). Kajian pemetaan tingkat kerawanan banjir dengan menggunakan system informasi geografis (studi kasus DAS Beringin, Kota Semarang).Jurnal Geodesi Undip. 4(2).

Solahuddin, M. (2014). SIG Untuk Memetakan Daerah Banjir Dengan Metode Skoring Dan Pembobotan (Studi Kasus Kabupaten Jepara).Jepara : Udinus.

Suhardiman. (2012). Zonasi Tingkat Kerawanan Banjir Dengan System Informasi Geografis (SIG) Pada Sub DAS Walanae Hilir. Makassar : Universitas Hasanuddin.

Sukirno, Setyawan, C., \& Sipayung, H.(2013). Kajian Kerawanan DAS Wawar. Nasional Sains \& Teknologi V Lembaga Penelitian Universitas Lampung.19-20 November. 